\title{
Whose river is it? An assessment of livelihood and cultural water flow requirements for the Karnali basin
}

\author{
Akriti Sharma $^{1}$, Emma Karki $^{1}$, Nishadi Erivagama ${ }^{1}$, Gitta Shrestha ${ }^{1}$, Marc Jeuland $^{2}$ and Luna Bharati $^{1}$
}

\begin{abstract}
The term "environmental flows" refers to a combination of features, including quantity, quality, and timing of water flows required to sustainably maintain a river's health, balancing both ecological and societal needs. Incorporating basic human livelihood and sociocultural aspects in environmental flow assessments alongside ecological concerns provides a more holistic perspective on water flow management. Here, we provide an assessment that complements an ecosystem functioning lens by focusing solely on quantifying the flows associated with livelihood activities and spiritual water requirements of local riparian communities in the Karnali basin in Western Nepal. This assessment is based on the first social survey related to environmental flows conducted in the Karnali basin. We collected data using mixed methods, including social surveys, key informant interviews, and focus group discussions, across six locations in the Karnali basin that provide us with a rich and dynamic perspective on the relationship between rivers and their surrounding communities, and the challenges faced by those communities. Among the subsistence and spiritual requirements of local communities are uses for activities that include drinking, small-scale irrigation, domestic needs, fishing, and ceremonial usage. All communities we visited most strongly associated the following activities with water flow variation: small-scale irrigation, fishing, ceremonial usage, domestic needs, and tourism. The water flows required for these key activities were quantified, and results from the six sites are presented in the form of a qualitative scale of minimum water levels (ranging across poor, acceptable, and ideal) required to meet vital local needs. The minimum acceptable water flow requirement to satisfy social criteria is just $>20 \%$ of the mean annual runoff at the visited locations. These requirements are particularly vital to consider, given ongoing efforts to tap the vast hydropower potential in Nepal through construction of major storage projects. Such projects would change the flow regime of affected rivers and potentially raise concerns that existing demands might be compromised.
\end{abstract}

Key Words: environmental flow; holistic water management; socioeconomic factors

\section{INTRODUCTION}

Nepal has abundant water resources, with an estimated 6000 rivers that are fed by monsoonal rains, melting snows, and the glaciers of the Himalayas (Aryal and Rajkarnikar 2011). Although river discharge varies greatly between the monsoon and dry season, these rivers continue to be an indispensable source of water for communities throughout the Mountain, Hilly, and Southern Plains (Terai) regions of the country. Households who are directly dependent on river water use it for an array of consumptive activities, including drinking, cooking, irrigation, livestock rearing, and household chores. In addition to these uses, rivers support livelihood activities such as fishing, tourism, and transportation, and are fundamental to some ceremonial activities.

Nepal's water resources, if managed efficiently, have the potential to contribute significantly to economic growth and sustainable development of the country. The available water resources could generate hydroelectric power and provide water for irrigation, domestic, and industrial uses (Aryal and Rajkarnikar 2011). Many rivers in Nepal have untapped potential for hydropower development, and the various associated investments could help Nepal to meet its electricity demand with renewable and climatesensitive power supply. The estimated potential for hydropower in Nepal is $83,000 \mathrm{MW}$, of which approximately $43,000 \mathrm{MW}$ is identified as economically viable (IHA 2018). Until now, only approximately $2 \%$ of this total potential has been used (Bharati et al. 2014). The government has a short-term goal to generate up to $4000 \mathrm{MW}$ of hydropower by 2027 to meet the projected domestic demand (Aryal and Rajkarnikar 2011). As a result, several hydropower projects have been approved and are underway across major river basins of the country, including the Karnali basin.

Although a majority of hydropower projects tend to be run of river, such projects can be just as disruptive of the natural flow as storage dams or weirs (Anderson et al. 2015). The diversion of flow, from the point of water abstraction to reintroduction into a river stretch, can deplete local water levels while hydropower generation is occurring (Anderson et al. 2015). Hydropower plants that divert water can harm surrounding ecosystems and communities (Liu et al. 2016). They can directly influence riparian ecosystems, water quality, and siltation, thereby altering the natural landscape (Biggs et al. 2005, Adhikari 2006).

The term "environmental flows" (e-flows) is typically used to describe a flow regime that maintains different components of a river's ecosystem in a prescribed state of ecological health while being subjected to water resources development. In 2018, the Brisbane Declaration and global action agenda on environmental flows updated the definition of e-flows as "the quantity, timing, and quality of freshwater flows and levels necessary to sustain aquatic ecosystems which, in turn, support human cultures, economies, sustainable livelihoods, and well-being" (Arthington et al. 2018). The different ecosystem components include riparian ecosystems, linked wetlands or floodplains, estuaries, and the various plant and animal species within the water system (King 2016). The updated 2018 definition also highlights human 
dependence on riparian ecosystems. However, we argue that human dependence on the river is more than just on ecosystems and related services.

Changes in the timing of river system flow patterns have the potential to disrupt the livelihoods and cultural activities of riparian communities. Rivers are considered sacred within the Hindu religion and provide critical support to the way of life of not only the communities who live within the hydrological basin but also those who live outside it. This sacred water plays an integral role throughout people's lives, from irrigating paddy fields to bathing the dead during ceremonial rites (Narayanan 2001). This role is especially true for the many rivers in the South Asian subcontinent that are worshipped as deities (Lokgariwar et al. 2014). Rivers in Nepal are no exception. However, few studies have considered socioeconomic dimensions of river health in Nepal.

When a river's water resources are being developed, maintaining all components of its natural flow regime intact may not be practical. Rivers may also exhibit a certain resilience or some ability to recover from negative development-induced shocks. As such, a compromise has to be reached between satisfying the evolving human demands for economically important uses of water and maintaining the ecological health of a river. Defining e-flows helps to guide decisions about this compromise, specifically by aiming to ensure that river water abstractions are restricted to (acceptable) levels that do not correspondingly destabilize other sensitive ecosystem services.

Despite the usual focus on ecological health, we argue here that e-flows can be equally critical for maintaining human well-being that is not directly dependent on ecosystem services. When such a definition is incorporated into environmental impact assessments in Western Nepal, it can help to improve decisionmaking on how to divide water among the competing needs of cultural, economic, and ecological interests when abstracting water for industrial projects. A healthy river may support local livelihoods and hold significant aesthetic, cultural, and religious values (Alston and Mason 2008) so that incorporating livelihood and sociocultural factors into e-flows provides a more holistic concept for the management of river health. Processes and tools already exist to ensure that water resources development and management are consistent with maintenance of healthy rivers, even as debates over the "preferred" state of the river persist (Sadoff and Grey 2002). For example, the basis for water resource management stems primarily from Western science and cultural values, which often fail to adequately reflect the values, needs, and management practices of indigenous communities (Tipa 2009). In a study linking cultural indicators of Maori people and scientific measures, researchers noted the important alignment of overall perspectives of indigenous peoples and other stakeholders, despite differences, indicating the strength of combining the two approaches to enhance the understanding of river health (Harmsworth et al. 2011). Another study from the upper Ganga River indicated that flows deemed critical for meeting cultural requirements match closely with those that maintain biota and natural processes (Lokgariwar et al. 2014).

There are limits to how much natural systems can be exploited without causing irreparable damage, which makes it crucial to define e-flow requirements during the planning stage of development if these natural systems are to be protected (Richter et al. 2003). Such requirements should give substantial, and possibly equal, weight to ecological and livelihood or cultural indicators. However, the process of establishing such indicators and requirements calls for extensive data collection that includes hydrological and sociocultural data, and methods for characterizing ecosystem services and assets of significance (Jain and Kumar 2014). Against the backdrop of current interest in expanding hydropower in Nepal, we here illustrate one such attempt. It is geared at incorporating subsistence needs for food and water, and spiritual values of local communities, into e-flow requirements at selected riverine sites in Western Nepal. The data collected were also incorporated into the Western Nepal Environmental Flow Calculator (WENEF) that was designed for the Karnali basin at selected riverine sites in Western Nepal. This software package for desktop assessment was developed by the International Water Management Institute (IWMI) under the U. S. Agency for International Development-funded Digo Jal Bikas (DJB) initiative (IWMI 2018).

Although the definition of e-flows includes "quantity, quality and timing" of water flows, our focus is exclusively on the quantity and timing of required flows to sustain ecosystems and sociocultural requirements at different riparian locations. We hope that this analysis will contribute to development of a more sustainable and just planning process for future development of water resources in this region.

\section{METHODS}

A holistic concept of e-flows refers to a hydrological condition that sustains freshwater ecosystems along with the livelihoods and well-being of human populations that depend on them (Forslund et al. 2009). Depending on how organizations define these indicators, the identified methodology for an e-flows assessment can differ. In the context of Nepal, with the recent policy focus on hydropower development and associated water storage projects, we hope to develop a better understanding of how various livelihood and sociocultural aspects can be incorporated into a sustainable riverine health concept.

A combination of qualitative and quantitative data indicating water depth requirements and uses of water was collected from the selected field sites across the Karnali Basin. This information was then analyzed to identify and create an inventory of indicators related to various water-dependent sociocultural services in the region. The amount of water needed, or the e-flow requirement, to maintain each of these identified prime indicators was then evaluated and quantified into an indicator based on the depth of water (in meters) required for specific purposes. These data were then converted into required water discharges based on river cross sections and water velocities at field sites (Eriyagama et al. 2019), which were collected as part of a parallel study on macroinvertebrate communities (Shah et al. 2020). In Fig. 1, we outline the basic methodology for the cultural and socioeconomic analysis, along with its role in the larger WENEF.

To strengthen our analysis, we refer to IWMI's expansive database from the DJB project conducted in the Karnali basin. This extensive data set was the product of a representative survey of 4305 respondents in the Karnali basin of Western Nepal. It provided our study with supporting evidence and data on water management systems in the selected regions of Western Nepal, 
Fig. 1. Methodology for the environmental flow study, based on Crow et al. (2018).

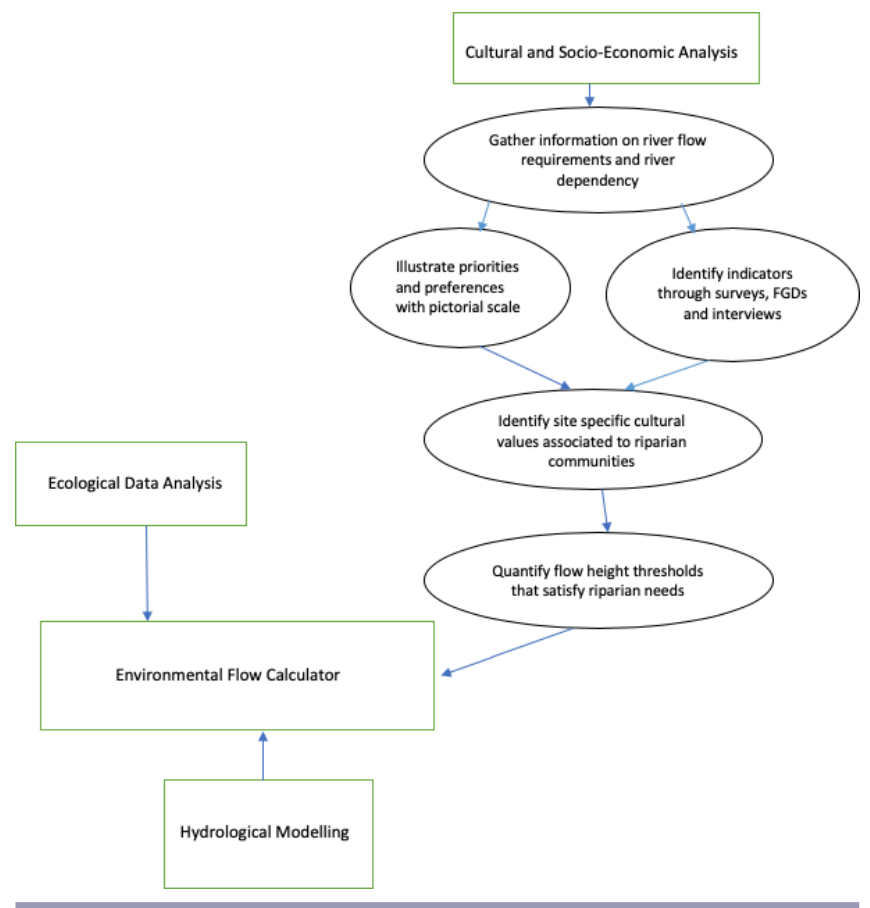

Fig. 2. Locations of hydropower projects in various stages of development and protected areas in the Karnali-Mohana and Mahakali basins, Western Nepal.

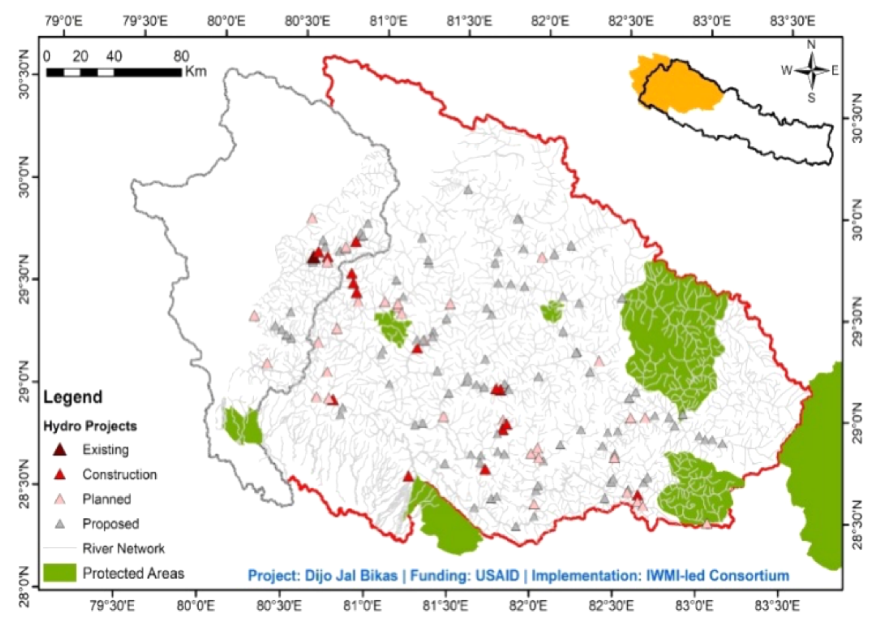

including the locations of existing, planned, and future hydropower and irrigation projects (Fig. 2). The Karnali basin is currently an area of key interest for hydropower projects.

\section{Site selection}

The analysis uses data collected from five riparian communities within the Karnali basin in February 2018. Six locations spanning the Mountain, Hill, and Terai regions were retained to capture the topographical, ecological, and ethnic diversity of the region. The visited locations in the Mountain region were Deura in Bajhang District and Bauligad in Bajura District. In the Hill region, the visited locations were Dungeshwor in Dailekh District and Drikeni and Garkhet in Achham District. A lack of a heterogeneous ethnic population led our team to visit two separate neighboring hamlets in Achham. In the Terai, the two visited villages were Kuti and Sunaphata in Kailali District.

The study sites were chosen based on two criteria. First, they were identified based on their inclusion in a parallel study of macroinvertebrate richness and abundance (Shah et al. 2020), the purpose of which was to collect samples at sites having different river morphologies and representing both natural and disturbed areas. Natural sites were defined as having "very minimal anthropogenic impacts and near-pristine conditions", whereas disturbed sites had stretches that included dams and/or weirs (Shah and Sharma, unpublished report). Water sampling was carried out at each location based on strict protocols, and the ecological status was determined on the basis of a screening protocol set by Hartmann et al. (2010) and Shah and Shah (2012). The parallel study of macroinvertebrates selected rivers based on river water quality, as assessed using water $\mathrm{pH}$, temperatures, and dissolved oxygen levels. The selected rivers met the requirements of the screening process and were of "quality class 1 or 2 " and were not directly affected by organic pollution (Shah et al. 2020).

Once a number of suitable macroinvertebrate sampling sites had been identified, they were cross-checked within the DJB data set. This process helped to identify six locations that were situated along a large river tributary and in close proximity to a settlement. All selected settlements were along the river bank or on a slightly elevated ridge next to the river bank. In all cases, the river was easily accessible to communities. Sites were intentionally selected in this manner to capture the close relationship between communities and the river. The selected sites also met the requirements for topographical, ecological, and ethnic diversity. The coordinates were mapped and the locations are shown in Fig. 3.

Fig. 3. Locations of sites selected for social surveys.

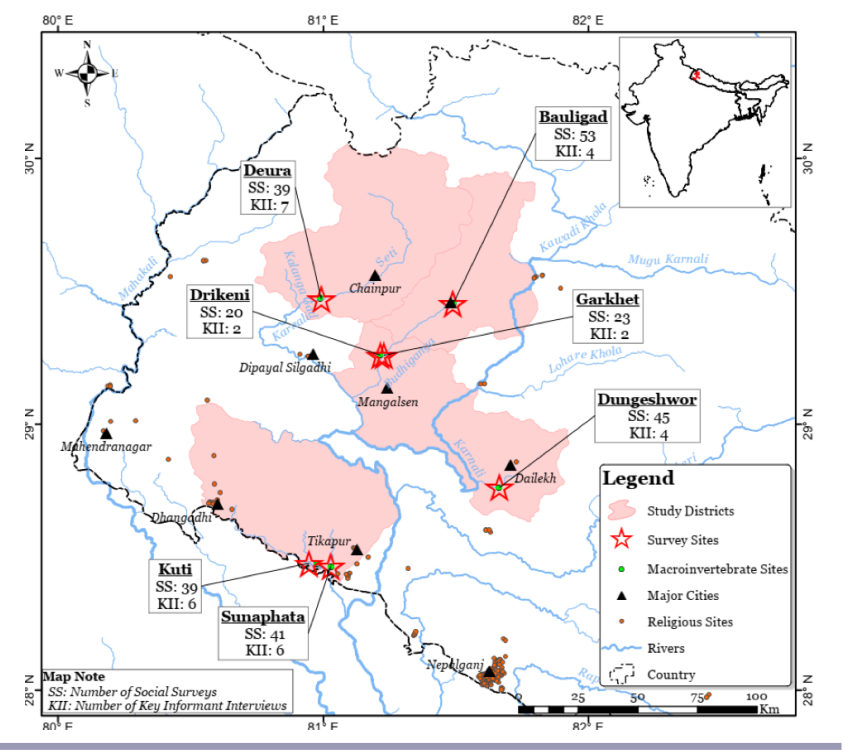




\section{Data collection}

Our focus was on local communities that largely depended directly on river water resources for their subsistence. The questionnaires provided information on river-related activities for economic, cultural, and livelihood purposes. To the extent possible, the water quantities and flows required for maintaining these various activities were assessed.

Data collection comprised social surveys to obtain qualitative and quantitative household-level information, key informant interviews, and focus group discussions that detailed the relationship between the communities and surrounding rivers. To assess and analyze the significance of the river to surrounding communities, two separate survey teams visited three locations each in February 2018, managing study time constraints. Each team included Nepali members who spoke the local language, underwent enumerator training based on a set of organizational guidelines, and used the same instruments and equipment to ensure standardized procedures.

Approximately 260 social surveys were conducted across the five selected communities. All interviews and focus group discussions were conducted and recorded with the consent of all participating respondents. At each location, the team first met a representative from the Village Development Committee along with some locals who joined on a voluntary basis to establish a map of the village and conduct a social wealth ranking. The Village Development Committee is the lowest tier of administrative government as part of the Ministry of Federal Affairs and Local Development. This process allowed both teams to identify and later survey members from different backgrounds within the local community, including the most influential and the most marginalized community members. All surveys were voluntary and were based on a referral sampling method with the aim of capturing a sample that represented the ethnic and wealth tiers within the village.

Although the aim was to collect approximately 30 surveys in each location, the number of respondents differed depending on the ethnic heterogeneity of the location (Table 1). If the majority of a settlement was found to belong to the same caste, the team traveled to neighboring hamlets or settlements to capture other ethnic perspectives within the selected location. All neighboring settlements were within walking distance of each other to ensure proximity to the river.

Table 1. Gender and ethnic composition of respondents from communities in three regions surveyed across the Karnali basin, Western Nepal.

\begin{tabular}{|c|c|c|c|c|c|c|}
\hline \multirow[t]{2}{*}{ Region } & \multicolumn{2}{|c|}{ Gender } & \multicolumn{3}{|c|}{ Ethnicity } & \multirow{2}{*}{$\begin{array}{l}\text { Households } \\
(N)\end{array}$} \\
\hline & Male & Female & $\begin{array}{c}\text { Brahmin/ } \\
\text { Chettri }\end{array}$ & Minority & Dalit & \\
\hline Mountain & $46 \%$ & $55 \%$ & $59 \%$ & $20 \%$ & $22 \%$ & 92 \\
\hline Hill & $47 \%$ & $54 \%$ & $61 \%$ & $22 \%$ & $18 \%$ & 88 \\
\hline Terai & $54 \%$ & $47 \%$ & $21 \%$ & $66 \%$ & $15 \%$ & 80 \\
\hline
\end{tabular}

Questionnaires and protocols were generally kept consistent, but some aspects were specifically tailored to the unique geographies of different areas. For example, location-specific occurrences such as landslides were assessed only in the Mountain and Hill regions, whereas questions related to riverbank farming activities were applicable mostly in the Terai region.

Additional focus group discussions were held with male and female respondents, who covered a range of ages, to deliver insights on gender-specific and generational heterogeneity in local communities' relationships with the river. These focus group discussions with community members who knew each other also allowed data to be gathered through collective memory, especially when it came to detailing the information related to historical flows and recent economic developments within the communities.

Assessing cultural flows is based on a community's values, opinions, and ideals, along with quantitative data about water flow and volume. The survey left questions specific to water-level parameters open ended so as not to sway the respondents or limit them to any set ranges. Some respondents gave quantitative amounts, whereas others used their body for approximations or used landmarks to distinguish water levels with additional anecdotal data. To obtain further information on current and ideal flow regimes, respondents were also asked to describe the differences in the appearance of the river, along with aquatic life and the biodiversity of their village. The collected responses, based on all the gathered quantitative and qualitative data helped identify the parameters (Table 2).

\section{RESULTS AND DISCUSSION: AN ANALYSIS OF WATER RELATIONSHIPS}

\section{What is the value of a river?}

The data show high rankings of importance and dependence of riparian communities on rivers for a range of purposes (Fig. 4). Because all visited sites were located by rivers, locals were noted to use river water for a majority of their needs, including irrigation, domestic activities, fishing, and in certain places, drinking. Respondents valued the river as a vital resource of which the uses ranged across domestic and religious purposes. Based on Hindu scriptures, rivers originate from the heavens, rendering them divine (Warrier 2014). Hindu temples are often located adjacent to rivers, and many religious ceremonies require holy river water, known as jal. The Ganga, or Ganges, is the most sacred river for Hindus, and the Karnali, one of its major tributaries, is consequently considered auspicious.

Fig. 4. Percentage of respondents surveyed in each of three regions across the Karnali basin who use river water for common activities. $N=260$.

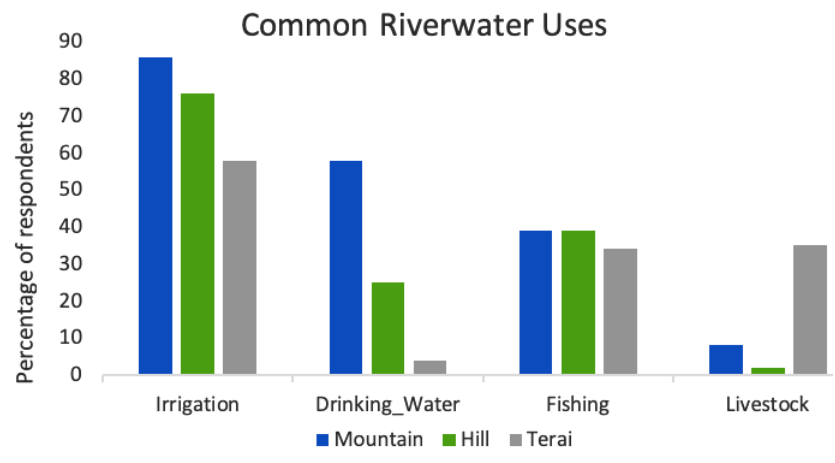


Table 2. Water depth indicators for livelihood requirements from rivers.

\begin{tabular}{|c|c|c|c|}
\hline Use & Ideal level (m) & Acceptable level (m) & Poor level (m) \\
\hline \multirow[t]{4}{*}{ Irrigation } & 0.9 & 0.5 & $\leq 0.10$ \\
\hline & $\begin{array}{l}\text { All families in a settlement can collect or } \\
\text { divert sufficient water through canals for } \\
\text { irrigation }\end{array}$ & $\begin{array}{l}\text { Families who wish to irrigate can } \\
\text { continue to do so and can ideally } \\
\text { reduce their reliance on rainwater }\end{array}$ & $\begin{array}{l}\text { Levels }<0.10 \mathrm{~m} \text { could result in negative return for } \\
\text { farmers, leading to more outmigration to search for } \\
\text { alternate income sources }\end{array}$ \\
\hline & $\begin{array}{l}\text { Can possibly reverse adverse impacts on } \\
\text { crop production and satiate household } \\
\text { needs for consumption }\end{array}$ & $\begin{array}{l}\text { Families in the Terai who grow crops } \\
\text { on a commercial scale can continue } \\
\text { to do so }\end{array}$ & $\begin{array}{l}\text { Water pumps and engines are likely to be damaged and } \\
\text { not function }\end{array}$ \\
\hline & & & $\begin{array}{l}\text { Families who currently practice commercial farming } \\
\text { may become fully reliant on underground water } \\
\text { resources or may need to seek alternate sources of } \\
\text { income }\end{array}$ \\
\hline \multirow[t]{4}{*}{ Fishing } & 1.5 & 0.9 & $\leq 0.30$ \\
\hline & $\begin{array}{l}\text { Allows ample water for locals to find } \\
\text { fish, provided that water quality is } \\
\text { acceptable }\end{array}$ & $\begin{array}{l}\text { Allows enough space for a variety of } \\
\text { fish to swim comfortably, allowing } \\
\text { current fishing activity levels to be } \\
\text { maintained }\end{array}$ & $\begin{array}{l}\text { Will not satisfy current fishing activity, negatively } \\
\text { affecting livelihoods }\end{array}$ \\
\hline & $\begin{array}{l}\text { Nets, traditional balchis, and fishing } \\
\text { rods will all work successfully }\end{array}$ & $\begin{array}{l}\text { All popular fishing methods can still } \\
\text { be practiced }\end{array}$ & $\begin{array}{l}\text { Nets that require submersion may no longer be } \\
\text { efficient }\end{array}$ \\
\hline & $\begin{array}{l}\text { Provides enough space for the larger } \\
\text { species of fish that locals say are no } \\
\text { longer available }\end{array}$ & & $\begin{array}{l}\text { High levels of suspended sediment may become more } \\
\text { apparent with lower water levels and negatively affect } \\
\text { aquatic habitat }\end{array}$ \\
\hline \multirow{5}{*}{$\begin{array}{l}\text { Sociocultural } \\
\text { and spiritual }\end{array}$} & 1.2 & 0.9 & $\leq 0.50$ \\
\hline & $\begin{array}{l}\text { Allows individuals to immerse } \\
\text { themselves fully in the river to take part } \\
\text { in cleansing and bathing rituals }\end{array}$ & $\begin{array}{l}\text { Enough water to be able to submerge } \\
\text { below the waist }\end{array}$ & $\begin{array}{l}\text { Levels are insufficient for individuals to completely } \\
\text { submerge and bathe in the river }\end{array}$ \\
\hline & $\begin{array}{l}\text { Necessary to satisfy spiritual needs } \\
\text { during various festivals }\end{array}$ & Ensures consistent flow & $\begin{array}{l}\text { Does not ensure the uninterrupted flow of the river to } \\
\text { wash away ceremonial blessings and offerings }\end{array}$ \\
\hline & $\begin{array}{l}\text { Ensures continuous flow for the } \\
\text { Dahasanskar ceremony }\end{array}$ & $\begin{array}{l}\text { Enough water for all members of } \\
\text { society to continue partaking in their } \\
\text { customs and practices }\end{array}$ & $\begin{array}{l}\text { At most, families can collect water in buckets to } \\
\text { shower if they wish }\end{array}$ \\
\hline & $\begin{array}{l}\text { Enough water for all members of society } \\
\text { to partake in their customs and practices }\end{array}$ & $\begin{array}{l}\text { Marginalized communities will not } \\
\text { have to find alternate solutions for } \\
\text { the Dahasanskar ceremony }\end{array}$ & $\begin{array}{l}\text { Families may choose to bury their dead instead, } \\
\text { altering their traditional and cultural practices }\end{array}$ \\
\hline \multirow{4}{*}{$\begin{array}{l}\text { Household } \\
\text { activities }\end{array}$} & 1.2 & 0.7 & $\leq 0.40$ \\
\hline & $\begin{array}{l}\text { Guarantees that the remaining local } \\
\text { water mills will function safely and well }\end{array}$ & $\begin{array}{l}\text { Supports safe functioning of a water } \\
\text { mill }\end{array}$ & $\begin{array}{l}\text { Levels }<0.40 \text { will not support water mills and will lead } \\
\text { to widespread closures }\end{array}$ \\
\hline & $\begin{array}{l}\text { Beyond this, there will still be enough } \\
\text { water in the river for all community } \\
\text { members' household activities }\end{array}$ & $\begin{array}{l}\text { Will provide families with enough } \\
\text { water to carry out household } \\
\text { activities }\end{array}$ & $\begin{array}{l}\text { Insufficient water to sustain an entire village's } \\
\text { livelihood activities without turning to other water } \\
\text { sources }\end{array}$ \\
\hline & & & $\begin{array}{l}\text { Care for livestock and washing larger cattle in the river } \\
\text { may no longer be possible } \\
\text { Difficult to maintain and continue growing vegetables } \\
\text { in homestead gardens }\end{array}$ \\
\hline \multirow{4}{*}{$\begin{array}{l}\text { Tourism, } \\
\text { recreation, and } \\
\text { biodiversity }\end{array}$} & 3.00 & 2.00 & $\leq 1.5$ \\
\hline & $\begin{array}{l}\text { Sustains the biodiversity, particularly of } \\
\text { the crocodiles and endangered dolphin } \\
\text { present in the Karnali basin }\end{array}$ & $\begin{array}{l}\text { Allows dolphins to swim comfortably } \\
\text { and crocodiles to navigate the rivers }\end{array}$ & $\begin{array}{l}\text { Water levels will not support the endangered dolphin } \\
\text { and will likely harm them or drive them into the } \\
\text { deeper rivers of India }\end{array}$ \\
\hline & $\begin{array}{l}\text { High water level is very important for } \\
\text { activities such as rafting }\end{array}$ & $\begin{array}{l}\text { The environment by the river banks, } \\
\text { where many picnic spots are located, } \\
\text { will continue to be cherished and } \\
\text { visited for recreational purposes }\end{array}$ & $\begin{array}{l}\text { Crocodiles may also migrate due to insufficient water } \\
\text { levels }\end{array}$ \\
\hline & $\begin{array}{l}\text { Certain parts of the river will remain } \\
\text { safe for swimming }\end{array}$ & & $\begin{array}{l}\text { Such low water levels may reveal pollution and trash } \\
\text { on the riverbanks, making picnic spots no longer } \\
\text { appealing }\end{array}$ \\
\hline
\end{tabular}

Rivers and riverbanks provide an important site for recreation. Young adults and families noted that they enjoyed visiting these locations for picnics during holidays and festivals. This use was more common in the Mountain and Hill regions than the Terai, presumably because the surrounding view of the river is more alluring. Children frequent the river during the dry season, when water levels are safe for swimming, and to engage in recreational fishing. More broadly, the riverbank acts as a site for interaction with neighboring villagers. For women traveling together with other women, the river provides an opportunity to share concerns and seek advice. Women rarely occupy public space in the visited communities and are often confined to the private sphere. The simple act of traveling together to take a bath strengthens communal ties and provides a break from household chores and drudgery. 
The Karnali River is also home to the endangered Gangetic river dolphin in Kailali District. The Gangetic dolphin is found only on the Indian subcontinent and requires deep-water channels. This species resides in the Terai region of the Karnali River between late June and September, when river levels rise. It frequents the rivers surrounding Sunaphata village in Kailali during the monsoon, and attracts local and international tourists, who stay at homestays located in the area. Proper management of these rivers is widely seen as providing an opportunity to develop tourism activities that can contribute to local sustainable development. Although tourism also has negative effects on the local environment related to population inflow, habitat destruction, and associated waste generation, they do not appear as a major current threat to the ecological integrity of the Karnali basin, largely owing to the historical isolation and lack of overall development of the region.

\section{How much are rivers contributing to economic sustenance?}

The engagement of households in resource-intensive activities and labor allocation decisions is strongly linked to their finances and economic well-being. Nepal is primarily an agrarian society in which approximately $66 \%$ of the population is involved in farming activities (FAO 2018). The surveyed populations showed varying reliance on river water for their subsistence and economic needs, with the dependence on river water for irrigation varying according to geographical region. In the Mountain and Hill regions, $86 \%$ and $64 \%$ of households relied on river water for irrigation, respectively, and the primary use of agricultural production is for a household's own consumption or subsistence. Locals diverted river water through irrigation channels, and some communities lifted water from larger river tributaries located beneath the ridge of their villages. In contrast, commercial-scale farming is more common in the Terai region, where land is fertile, access to groundwater is easier, and growing conditions are relatively favorable.

Fishing was also noted as a major activity across the Karnali basin; approximately $60 \%$ of respondents had a family member who partakes in some form of fishing or shellfish capture. More than $50 \%$ of the surveyed population said that the primary purpose of fishing is for household consumption. Fishing activity is quite sensitive, with certain months being perceived as ideal for fishing in the Mountain and Hill regions (Fig. 5). In those regions, optimal conditions tend to occur during the post monsoon seasons, when the river is not flooded and is therefore safe. However, in the Terai region, the preferred season for fishing is peak monsoon because the generally dry river is abundant with water during that time. Furthermore, fishing is an occupation that is closely tied to ethnicity in rural areas, where families belonging to the Chaudhary caste are much more likely to fish, and to sell their produce either locally in their village or in nearby towns. The related income depends on the market price of the catch, and with depleting fish populations, fishing is no longer a stable source of income for families who have been pursuing this activity for generations. Young children also fish, often as a recreational activity, but also to provide income needed for purchasing school supplies. A small number of families were noted to own and operate water mills in the Mountain and Hill regions. These mills are generally open to local community members and people from neighboring villages. The mills are used in exchange for a small fee or other goods, including rice and flour.
Fig. 5. Percentage of respondents' preferred seasons for fishing for communities in each of three regions across the Karnali basin. $N=260$.

\section{Preferred Fishing Season}

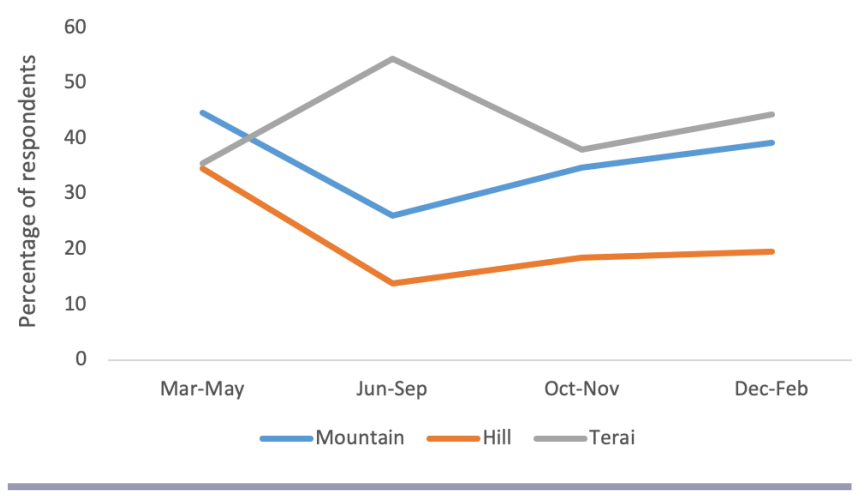

What is the relationship between the river and cultural values? Uses of river water for sociocultural aspects include ritualistic bathing and ceremonial usage. Holy rivers such as the Karnali are believed to have self-purifying properties, and the Ganga's healing power is described in many historical and religious texts (Singh 1994). The belief system is so strong that water from the Ganga is not required to meet any quality standards (Kumar 2017). The belief is that running water signifies purity, so for rural communities in the Karnali, visible cleanliness is considered secondary, given that the river itself is considered sacred. Respondents were willing to drink and bathe in river water, despite its murkiness, for religious ceremonies and rites, considering that it had a continuous flow. Furthermore, the confluence of two or more rivers is considered of high spiritual significance. Two such locations were identified in Drikeni, Accham and Deura, Bajhang. The Seti and Kalanga rivers meet in Deura, Bajhang, whereas Tare Kuna is the meeting point of Budhiganga and Jijadigad rivers. Locals and neighboring villages identified these confluence sites as extremely auspicious locations for ceremonies, including weddings.

Many Hindu rituals and festivals require the use of holy river water. Stemming from the belief that the river cleanses the body from committed sins (Agoramoorthy 2015), many festivals include a bathing ritual that is performed by either completely immersing oneself in the river or by collecting the water in a container and pouring it over the top of one's head. The Sanskrit word snâa, or cleansing, refers to the washing away of sins and immoralities through ritualistic bathing. Approximately $83 \%$ of surveyed respondents recounted using water from the surrounding rivers for religious purposes, with no notable distinction between male and female respondents. Our data also suggest that these uses do not seem to change within generations, with respondents as young as 17 noting that they believe in the river's spiritual value and collect $j a l$ for traditional practices. The jal from the river is preferred over water from communal taps, for which a constant flow cannot be guaranteed. Although respondents from differing castes celebrated a variety of festivals and rituals, jal was found to be incorporated in all of them. Among 
the most integral rituals for Hindus remains the Dahasanskar, or funeral ceremony. This river plays a vital role here, as a continuous flow is required to allow the pinda, an offering to the ancestors during funeral rites, to flow away and is able to wash away all ceremonial blessings.

Among the festivals identified in the survey, the three most common that involved river water were Maghesakranti, Shivaratri, and Teej. Similar to the solstice, Maghesakranti is celebrated in the spring by different ethnicities. Shivaratri, celebrated in the Nepali month of Phalgun (February-March), translates to "the night of Shiva" and marks the night that Shiva consumed poison to save the world. Teej falls in the late monsoon (August-September) and is observed only by women from specific castes, who fast for an entire day without water to ensure the prosperity of their current or, if unmarried, future husband. Shortly following this festival, women bathe in the river to seek forgiveness for immoralities they might have knowingly or unknowingly committed during menstruation. This practice is related to the strong existing taboos associated with menstruation.

\section{What are the current water systems like?}

Currently, there is limited water storage infrastructure available to households and communities in the Karnali basin. With no storage systems for long-term water collection and use, water withdrawal from the river must be frequent and is primarily dependent on the availability of river flows, which vary a great deal across seasons (Devkota and Gyawali 2015). The lack of storage has been a major disadvantage to a significant majority of the people living in the Karnali basin who depend on subsistence agriculture for their livelihoods (Devkota and Gyawali 2015). This situation was observed in the visited communities, where drinking water conveyance infrastructure was unequally distributed, with pipes diverted primarily toward wealthier households and away from local bazaars and other areas, leaving the most vulnerable unserviced. As a result, the most marginalized households continue to depend on river water for most or all of their consumptive needs, rather than collecting water from local taps. Watershed management and canal development projects throughout the basin, especially in the Terai region, can potentially increase access to both drinking and agricultural water supply and may also enable increased crop production and nonsubsistence agriculture. Changes in social norms, to allow more equitable access to watersheds by members from marginalized groups, would also contribute to more inclusive water and ecosystem management.

\section{How has the river evolved in relation to riparian livelihoods in the past two decades?}

With time and natural forces, it is inevitable that a river will slowly change its course and go through natural changes in flow patterns. However, respondents noted a significant change in river flow in the past two decades that they felt affected their livelihoods along with the surrounding ecosystems and natural environment. Respondents noted that a combination of rapid population growth and land conversion to settlements, coupled with decreasing river flow, had led to more intense water shortages. Consequently, respondents across all three regions perceived that irrigation and agricultural activities had declined in recent years, as families increasingly struggled to divert water to their fields and faced adverse effects on yields.
Fifty-five percent of respondents felt that the changes in the river had negatively affected their crop production in recent years. In Bajura, respondents perceived that dam-related water diversions for hydropower production had reduced the river's flow, subjecting women to new challenges as they struggle to use water for irrigation. Challenges with irrigation have forced many young adults, a majority of them male, to consider migrating to larger cities in the region or to other countries in search of alternative work opportunities. According to the Food and Agriculture Organization (2018), farmers are increasingly growing a diversified mix of crops to cope with weather variability. Not only have these conditions increased the workload and drudgery that falls to women in the region because of their lower propensity to migrate, but they have also lowered satisfaction levels with smallscale irrigation solutions and decreased the economic resilience and self-sufficiency of local communities.

Fishing activities were also noted to have declined over the years. Fishing communities reside along the Karnali and are fully dependent on the river to sustain their livelihoods. Some of these communities are made up of Dalits, who have been structurally, socially, and economically marginalized because they are considered among the "lowest" members of the existing caste system. Consequently, many lack the skills and education to diversify their livelihoods beyond fishing. Overall, 77\%, 78\%, 66\% of Mountain, Hill, and Terai region respondents, respectively, agreed that the overall quality of the river as well as the quantity of fish available had decreased. While the decrease in fish population can be attributed to overfishing and to a general increase in demand for fish by rising populations and tourists visiting the region, deteriorating river water quality also likely plays a role. An even larger proportion of respondents noted that reduced water levels were closely linked to the presence of smaller fish.

River changes have affected irrigation and fishing activities across the three regions (Fig. 6). It was also noted that agriculture is no longer a reliable source of income due to challenges related to crop production and the small size of land holdings resulting from high population growth in the surveyed villages. The exception to this general rule is in the Terai region (Fig. 6), where availability of groundwater provided respondents with a more secure and less seasonally variable water supply. Consequently, only $36 \%$ of those respondents mentioned that the change in river water had affected their irrigation activities. Additionally, several respondents mentioned that fish are no longer as abundant since water levels in the rivers have decreased. Respondents also expressed that the size of fish present in their rivers has been declining rapidly.

Lower water levels were also seen to affect tradition among local communities. Ideally, ceremonies and rituals require an individual to completely submerge themselves in the river by bending down. However, with declining levels of river water, respondents found that they cannot immerse in the water, which is considered an important aspect for festivals, including Teej and Maghesankranti. Furthermore, ceremonial rites called pinda must flow away with the river during the Dahasankar ceremony, which also marks the detachment from the physical body and Earth. In this ceremony, the river is believed to facilitate the spirit's journey to heaven (Warrier 2014, Kumar 2017). Considering the significance of this ritual to Hindus, it is noteworthy that some marginalized 
respondents in Dailekh are displeased that they must now bury their dead because of reduced river flow, as they cannot afford to travel to a neighboring settlement with better water levels to perform the traditional ceremonial rights.

Fig. 6. Percentage of households whose irrigation and fishing activites were affected by river changes in each of three regions across the Karnali basin. $N=260$.

\section{Impact on Livelihood Activities}

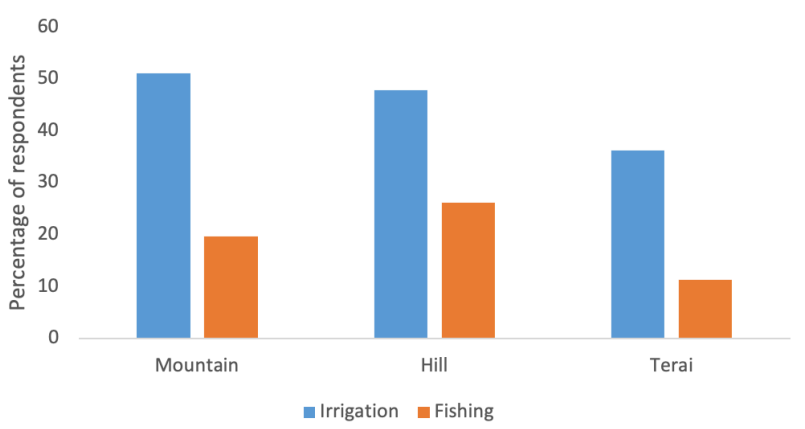

Respondents also mentioned that several water mills in the Hill region had recently been closed because of insufficient water levels. Some families chose to move toward the riverbank for easier access to the required water for milling, whereas others chose to forgo this economic opportunity due to lack of dependable river flow. Mill closure has increased the burden on women because they must travel farther and wait longer to process grain at alternative mills. Additionally, some farmers believed that the river water damages not only their crops but also their milling engines because of high levels of sediment and gravel.

While the Karnali basin is still a popular choice for rafting activities, decreasing water levels in the rivers are making it difficult to sustain the activity, especially along smaller tributaries. Locals in Dailekh recall rafting groups visiting roughly 15 to 20 years ago. Although these visitors never stayed overnight in the villages, they would stop to have a meal and interact with locals. Unfortunately, this activity ended when it was deemed too risky given low water levels in the river. This ecotourism activity is currently small in scale because of uncertainties over river water levels. Over time, locals also noticed that existing water channels may no longer be sufficiently deep for existing dolphin populations, although improved management of water flows should make it possible to continue to sustain these threatened animals.

\section{FURTHER WATER-RELATED CHALLENGES}

\section{Health and the impacts of pollution}

Healthy rivers have the potential to provide surrounding communities with a variety of benefits. The visited communities use water for drinking, cooking, bathing, and swimming, which are activities that bring them into direct contact with river water. Polluted water can spread common waterborne diseases, give people kidney stones, or cause skin diseases and rashes. Water pollution occurs through the accumulation of sewage, trash, or other unwanted substances in surface water bodies.
Although the surveyed communities no longer release sewage in the river, communities still use these natural conduits to dispose of animal carcasses and household trash, including glass bottles that have the potential to cause accidents in the river. Because the river is mostly seasonal, the consistency of water flows changes over the course of the year. Many respondents indicated that they had gotten sick in the recent past because of contact with polluted water. Some in the Terai region, where the water quality is comparatively worse, believed they had developed rashes from bathing in the river. The water during and right after the monsoon is usually murky, and community members would rather collect water for their daily needs from the public tap during this time. However, some marginalized community members answered that they continue to use river water due to lack of alternatives, although they know it is risky for health.

Similarly, $80 \%$ of the respondents indicated concerns about increasing risk of waterborne diseases, especially among younger children. Community members perceived an increase in kidney stones, stomach aches, and diarrhea. Nevertheless, community members in all visited locations felt that the volume of river pollution had decreased over the past five years owing to increased awareness about limiting pollution and to the fact that households have made investments in pit latrines. None of the surveyed communities were still directing fecal waste into the river.

\section{River and women in the Karnali}

Across generations in this region, women's relationship with rivers runs deep. Rivers have played a vital role for daily chores, religious activities, and irrigation practices, activities where women and young girls continue to hold primary responsibility. Within the Karnali and Mohana basins, $62 \%$ of women are primarily responsible for collecting water for household chores, livestock, homestead, and religious purposes (IWMI 2018). Survey data from the basin-wide survey show that among $88 \%$ of families who own livestock, $63 \%$ of the primary caretakers are women, whereas $9 \%$ are men (IWMI 2018). Research has documented that both collecting water and tending livestock are labor- and timeintensive chores (Meinzen-Dick and Zwarteveen 1998). In the Karnali basin, drying water sources exacerbated these burdens, forcing women to spend more time collecting water (Shrestha and Clement 2018). Water quality is further degraded when primary water sources used by livestock for drinking are turned into drainage flows. This conversion was noted by respondents in Bajura, where a natural stream that once ran through the settlement was turned into a drainage conduit for factory and household waste. Women reported animal diseases and death caused by the consumption of polluted water from the affected conduit, along with an increase in time spent collecting from clean water sources.

Because this survey took place among riparian communities, the majority of respondents used river water daily for their household chores. In Dailekh, $>50 \%$ women relied on river water for their homestead gardens. In Bajura, farms were located alongside the river, and women collected water for bathing, laundry, and livestock rearing. Respondents from Bajura explained that they experienced seasonally varying dependence on the river because water supply disruptions were common at public taps during the dry months between March and June. Women in Accham reported walking $>1 \mathrm{~h}$ one way to the Jijadigadi River to collect 
water. The reliance on natural rivers was greater among marginalized communities who could not afford alternatives such as taps or tube wells.

Women's dependence on rivers also stems from taboos surrounding menstruation. Although public taps recently constructed by government or development agencies tend to be inclusive and accessible, Dalits and menstruating women still commonly use separate taps or rely completely on the river for domestic water. Despite social discrimination, the river remains a freely accessible source of water. Women felt easier to cleanse themselves and wash stained laundry at the river because the continuous flow and velocity made the process quick and avoided socially constructed emotions, including shame and guilt, which are often linked with menstruation. This use does not alter the perception that jal continues to be pure, because the river's purity is embedded not solely in religious beliefs, but in maintenance of its continuous flow. In contrast, respondents believe that household water supplies do not hold this self-purification property.

Most respondents repeatedly mentioned risks from natural hazards, including landslides, erosion, and floods. The localized impact of such disasters places an additional burden on women because they must supply water and fuel for families while environmental changes pollute water supplies and damage existing infrastructure and settlements. Women's vulnerability is reportedly exacerbated by limited access to health facilities and education, as well as the technology required to anticipate and adapt to such disasters.

Male migration has also increased women's workload within the surveyed communities. Irrigation, once considered a man's job, is now increasingly undertaken by women. However, in the Karnali basin, only $25 \%$ of irrigation user group members are women (IWMI 2018). Additionally, marginalized women farmers are among the last to irrigate their fields due to a lack of sufficient labor and equipment and less favorable plot locations (Shrestha and Clement 2018). Women continue to be less involved than men in integral water resources decision-making processes. Our data support the existing literature (Crosgrove and Rijsberman 2000) indicating that women's voices in water- and river-related issues continue to be overlooked. To build sustainable systems that work for all, it is necessary to ensure that local residents, including women and marginalized communities, are involved in decisionmaking regarding the development of projects in their region that can ultimately affect their lives.

\section{TOWARD A MORE INCLUSIVE ENVIRONMENTAL FLOW}

To develop a holistic conception of e-flows that accurately identifies water depth and the volumes required for sustainable use, we defined five depth indicators for tracking the critical sociocultural and livelihood needs of populations in the Karnali basin based on the survey evidence. These indicators relate to needs for: (1) irrigation, (2) fishing, (3) rituals and festivals, (4) household activities, and (5) biodiversity and tourism. These five indicators cover the aspects that are most integral to human wellbeing in all three regions (Mountain, Hill, Terai). The parameters (Table 2) are recommendations based on our collected data and are explored in further detail below.
Throughout the basin, we identified a strong reliance on river water for daily needs, especially for irrigation and cultural activities. Although not all households within a community participated in fishing, a majority of them did purchase fish from other locals, and fish are a regular part of the local diet. Therefore, the existence of fishing activities is a relevant indicator of riparian communities' livelihood aspects. Important household activities include (but are not limited to) drinking, cooking, homestead gardens, bathing, washing clothes, feeding and washing livestock, and, where relevant, water mills. Most surveyed households use river water for at least one aspect of their household chores, the most common being for livestock and washing clothes. The final indicator of biodiversity and tourism includes dolphin health and occasional rafting levels.

\section{Irrigation}

The data suggest the ideal river water depth for irrigation activities to be approximately $1 \mathrm{~m}$, which corresponds to a discharge rate of $24.88 \mathrm{~m}^{3} / \mathrm{s}$ specifically at Kuti. This water level requirement allows all families within the settlements either to collect or to divert sufficient water through canals for their irrigation needs. An acceptable depth of $\sim 0.5 \mathrm{~m}$ or $14.28 \mathrm{~m}^{3} / \mathrm{s}$ discharge rate at Kuti would enable families to continue with their irrigation activities. Current data suggest that farmers tend to be hesitant to use their pumps when water levels are on the lower side because the sediment is known to ruin their pumps. Our data suggest that any level of water below $0.10 \mathrm{~m}$ or $3.459 \mathrm{~m}^{3} / \mathrm{s}$ discharge rate at Kuti is considered poor. Currently, most of the rivers in the visited locations in the Terai are at this level (Table 3), leading to a strong reliance on groundwater instead. Additionally, levels $<0.10 \mathrm{~m}$ could result in negative returns for farmers, creating a less favorable economy that could be one of the factors pushing more locals to consider outmigration among the younger generation in search of alternate income sources.

\section{Fishing}

Ideally, the river should have approximately $1.5 \mathrm{~m}$ of water, a depth that allows locals to find fish, provided that water quality is also acceptable. This depth allows nets, traditional balchis, and fishing rods to work successfully and should provide enough space for larger species of fish to repopulate the rivers. According to our data, the acceptable water depth is $\sim 1 \mathrm{~m}$, which would still provide enough space for swimming by a variety of fish, allowing current fishing activities to be maintained. At this depth, households can continue to practice the most common forms of fishing, using traditional balchis and fishing rods. Our data show that anything $\leq 0.3 \mathrm{~m}$ would threaten current fishing activities and therefore potentially harm livelihoods and aquatic ecosystems. Low water levels would reduce the efficiency of nets that require complete submersion. High levels of suspended sediment could also negatively affect aquatic habitat.

\section{Rituals and festivals}

Ideally, there should be enough water in the river for all community members to partake in their particular ceremonies without disruptions. Although different ceremonies require different levels of water, most festivals fall during the early spring and autumn seasons. No major water-related festivals occur between June and September, which corresponds to peak monsoon. According to our data, the ideal river depth is slightly $>1 \mathrm{~m}$, allowing individuals to immerse themselves fully in the 
Table 3. River discharge corresponding to identified minimum water depth at some locations. (The names of locations are indicative only and represent areas where river cross section and flow velocity data were available).

\begin{tabular}{lccccc}
\hline \hline Location & Watershed area $\left(\mathrm{km}^{2}\right)$ & $\begin{array}{c}\text { Average top width of } \\
\text { river }(\mathrm{m})\end{array}$ & $\begin{array}{c}\text { Discharge at } 0.1 \mathrm{~m} \text { depth } \\
\left(\mathrm{m}^{3} / \mathrm{s}\right)\end{array}$ & $\begin{array}{c}\text { Discharge at } 0.54 \mathrm{~m} \\
\text { depth }\left(\mathrm{m}^{3} / \mathrm{s}\right)\end{array}$ & $\begin{array}{c}\text { Discharge at } 0.97 \mathrm{~m} \mathrm{depth} \\
\left(\mathrm{m}^{3} / \mathrm{s}\right)\end{array}$ \\
\hline ChedaGad & 1023.9 & 17 & 1.070 & 4.43 & 7.97 \\
Kailash Kola & 255.17 & 13 & 0.296 & 2.299 & 4.29 \\
Kuti & 2440.85 & 26 & 3.459 & 14.28 & 24.88 \\
Dailekh & 782.89 & 24 & 1.014 & 2.744 & 2.447 \\
Suni Gad & 212.99 & 10 & 0.642 & 2.855 & 5.074 \\
\hline
\end{tabular}

river to take part in cleansing and bathing rituals. This depth also ensures a continuous flow for the Dahasanskar (funeral) ceremony, which Hindus consider extremely sacred. Our data suggest that water depth $\leq 0.5 \mathrm{~m}$ would be considered poor because it would not ensure the uninterrupted flow that is considered important. As noted in the survey, members from marginalized communities sometimes bypass practices altogether due to a lack of river water. Water levels $<0.5 \mathrm{~m}$ would allow families to collect water in buckets for showering, but they would likely be forced to bury their dead, altering their traditional and cultural practices.

\section{Household activities}

Ideally, there should be sufficient water levels in the river to allow households to use enough water for all their household chores as well as their water milling needs. According to the data, respondents prefer to have water depth $>1 \mathrm{~m}$ to guarantee that the remaining water mills function safely. An acceptable level of $0.7 \mathrm{~m}$ supports safe functionality of the water mills and provides enough water to sustain household activities. Any level $\leq 0.4 \mathrm{~m}$ will not support water mills, potentially leading to closures of these facilities. The collected data suggest that such levels could also hinder care for livestock because washing larger cattle in the river may become difficult. Households may also find it difficult to continue maintaining and growing vegetables in homestead gardens.

\section{Biodiversity and tourism}

To continue sustaining local wildlife, including the Gangetic dolphins, the river depth would need to be approximately $3 \mathrm{~m}$. These water levels may be needed only at particular locations. This water depth is much greater than that needed for other activities and stems partly from the level required to sustain the habitat of the endangered dolphins and the crocodiles present in the Karnali basin. High water levels are also important for tourism activities such as rafting and for maintaining attractive picnicking and recreation locations along riverbanks. An acceptable level of $2 \mathrm{~m}$ would ensure that dolphins and crocodiles could continue to swim comfortably and navigate the rivers, but it would not suffice for rafting. Our data show that anything $\leq 1.5 \mathrm{~m}$ would be considered poor because it would neither support the endangered dolphins and crocodiles nor be sufficient to maintain the aesthetic of riverbank recreation areas.

\section{Incorporation into the Environmental Flow Calculator}

To incorporate the identified social parameters successfully into the current iteration of the WENEF, the water depths were converted to their corresponding minimum discharge flow requirements based on river cross sections and water velocities (Eriyagama et al. 2019). Ongoing parallel research in the DJB project provided simulated monthly flow records for the six sites that were surveyed in this study.

For this iteration, the requirements of irrigation were identified as the overall lowest water requirement for riparian communities because this activity is vital for the surveyed communities' sustenance and economic needs. The corresponding water depths are $0.1,0.54$, and $0.97 \mathrm{~m}$ for poor, acceptable, and ideal water levels, respectively. Additionally, it was observed that the minimum flow depth of $0.1 \mathrm{~m}$ must be maintained in the river during the premonsoon season, when the river depth is at its lowest. The three depth values were converted into discharge values at locations where river cross section and flow velocity data were available. The results for a few locations are presented in Table 3. Similarly, minimum flow requirements to satisfy ecological thresholds based on macroinvertebrate richness and abundance were also determined. A minimum e-flow regime or monthly time series of flows was designed to satisfy both criteria. The flow regime specifies the minimum discharges that need to be maintained each month at specified river locations. Table 4 shows the proportion of time that the designed flow regime satisfies the water depth requirements of $0.1,0.54$, and $0.97 \mathrm{~m}$ for irrigation supply at the same locations shown in Table 3 . These times were estimated by calculating the proportion of time that the monthly discharges of the designed e-flow regime equaled or exceeded discharge values in Table 3 . The results showed that, in general, the minimum flow requirements to satisfy both the ecological and social criteria are just $>20 \%$ of the mean annual runoff at the estimated locations.

Table 4. Satisfaction of the minimum social flow requirement by the designed environmental flow regime.

\begin{tabular}{lccc}
\hline \hline Location & $\begin{array}{c}\text { Proportion of } \\
\text { time } 0.1 \mathrm{~m} \\
\text { depth is } \\
\text { satisfied (\%) }\end{array}$ & $\begin{array}{c}\text { Proportion of } \\
\text { time } 0.54 \mathrm{~m} \\
\text { depth is satisfied } \\
(\%)\end{array}$ & $\begin{array}{c}\text { Proportion of } \\
\text { time } 0.97 \mathrm{~m} \text { depth } \\
\text { is satisfied (\%) }\end{array}$ \\
\hline ChedaGad & 100 & $40-50$ & $30-40$ \\
Kailash Kola & 100 & $30-40$ & $10-20$ \\
Kandre River & 100 & $50-60$ & $30-40$ \\
Lohara Kola2 & 100 & $50-60$ & $40-50$ \\
Suni Gad & 100 & $30-40$ & 20 \\
\hline
\end{tabular}

\section{MOVING FORWARD}

How can local perceptions inform water management?

Research across the developing world suggests that neglect to incorporate community perceptions and cultural diversity in 
environmental impact assessments and social impact assessments can alienate the most affected people during key decision-making processes (Nzeadibe et al. 2015, Bennett 2016). If these analyses are not systematically carried out, they risk excluding certain individuals and groups. Time and again, those excluded are the most marginalized members of society, including women and members of disadvantaged castes. A community usually comprises multiple groups and individuals varying in socioeconomic status, culture, experience, motivation, attitude, instinct, and preference, to name a few aspects (Bennet 2015). Given the specific social context in which this community interacts, each place yields a unique set of perceptions that includes their observations, understanding, and evaluation of the surrounding world. It is vital to understand and apply these unique perceptions when undertaking conservation and environmental initiatives.

The results from our study, along with the ecological survey (Shah et al. 2020), allowed for the development of a more holistic iteration of the WENEF. This iteration incorporates hydrological modeling, ecology and macroinvertebrate data, and the socioeconomic survey analysis outlined here. The WENEF has an easy-to-use interactive interface with the goal of allowing policy makers and individuals to identify how much water extractive activities can affect downstream communities and ecosystems alike. This tool provides better knowledge control over water allocation projects and conservation efforts. Ideally, this project can be replicated throughout other basins in Nepal.

Although water collection and related tasks tend to be primarily the role of women, they continue to be disregarded in decisionmaking processes. This issue is highlighted in the larger DJB project, where it is noted that in the Karnali basin, only $25 \%$ of irrigation user group members are women (IWMI 2018). Research has continuously shown that reasons for women's absence in such spaces in South Asia include their hesitation to be part of a maledominated space, lack of awareness, and lack of available information (Wahaj and Hart1 2012). There is a clear need to raise local women's and marginalized groups' awareness of development projects in their region that can affect their livelihoods and well-being. Moving forward, women and socially marginalized groups, including the Dalit, should be consulted on issues related to water management, policy, and infrastructure decisions.

\section{How can this analysis be improved?}

To study the differences between the Mountain, Hill, and Terai regions effectively, we customized questionnaires that tackled specific agroecological issues, including landslides and riverbank farming. Although these differences do aim to make the questionnaire more efficient, we acknowledge that even subtle differences in instrumentation can have subsequent effects on the results, making cross-regional standardization difficult. However, due to the depth of knowledge about the regions and the supporting quantifiable data about these location-specific activities, we do not see this difference as a major threat to the interpretation of the results. Our study was also undertaken within the DJB project, a larger interdisciplinary study focusing on the Karnali basin in Western Nepal. Multiple approaches were used to collect primary and secondary data for the Karnali region, including an extensive socioeconomic survey of 4305 households, construction of a hydro-climatic database, analysis of plans for current and future planned infrastructure, natural resource management practices, as well as institutional assessment of relevant organizations working in water resource management in Nepal. Therefore, the researchers planned and developed the survey with a comprehensive understanding of the region.

Of course, there are some important limitations in the recommendations summarized in Table 2 . The study did not take account of the average velocity of the river and flow volumes during the social survey, which could further help to determine factors such as sediment deposition and cultural, especially religious, significance, or the sufficiency of surface water for local irrigation needs. With the current structure of the survey, no distinction was made concerning the seasonal variation in ideal water depth, meaning that the requirements could potentially be during a higher run-off period such as the monsoon or postmonsoon seasons. Multiple surveys during the pre- and postmonsoon periods might yield different responses and a data set that would be more illuminating about seasonal aspects of water use. Therefore, a year-round assessment of water levels in the river would allow more specific categorizations according to seasons and reduce the reliance on respondents' memories of other periods. Subsequently, it would then be possible to accurately estimate the discharges for all social parameters across all seasons.

Additionally, we acknowledge that the site selection process was limited by the methodology developed by the parallel macroinvertebrate study, which excluded the higher mountain regions. This process implies a gap in knowledge about an important ecological niche. Furthermore, the parallel study was not designed to be representative of the socioeconomic characteristics of local populations; our results should similarly not be considered representative. Finally, we note that river depths may be difficult to use for policy purposes because they will vary widely according to hyper-local river channel characteristics, whereas people planning and operating control infrastructures such as hydropower dams typically require information on minimum water flow rates. These limitations and challenges provide an opportunity for additional studies that will further strengthen the overall assessment.

\section{CONCLUSION}

This study has addressed a key gap existing in the current narrative of e-flows in Nepal by integrating livelihood and social aspects. It is the first social survey related to e-flows to be conducted in the Karnali basin. To date, although various environmental flow methodologies exist, they widely use ad-hoc measures of water quantity and quality needs, which are not informed by a holistic picture of a wide variety of ecosystem service needs. Especially critical is the fact that riverine ecosystems include indigenous riparian communities, who are dependent and interact with the river on a daily basis. This population, however, is often excluded from water resource planning initiatives. This report is part of a broader e-flows assessment that aims to integrate multiple aspects, including ecology, macroinvertebrates, biodiversity, and water quality to provide a comprehensive analysis of water needs in Nepal. Our research shows that river water levels have a direct effect on in-stream communities' well-being. 
With the recent restructuring of the federal system within the Government of Nepal, we see an opportunity for local government representatives to work closely with state or federal government to promote sustainable development. Water-level requirements for social and cultural parameters could potentially conflict with plans for discharge levels from new hydropower and other infrastructure. To ensure the protection of indigenous communities while supporting economic development, policy makers must also consider sociocultural requirements when determining the operating rules for such water control projects. A holistic desktop WENEF can contribute to making these informed decisions.

The sociocultural indicators identified here add a new dimension to the e-flows in the Karnali basin. We found that maintaining water-level requirements for household activities, irrigation, fishing, cultural practices, tourism, and biodiversity is vital to sustaining community livelihoods. Respondents' satisfaction levels were found to be highly responsive to changes in water depth, suggesting significant vulnerability to perturbations in water availability. The information obtained could aid in the establishment of national standards or guidelines for setting physical e-flow indicators such as turbidity, depth, flow rate, and volume that would adequately account for ecological and sociocultural vulnerabilities. Such standards would thereby inform or constrain operations of current and future water control and diversion projects, such that they do less damage to natural and anthropogenic needs.

Responses to this article can be read online at: http://www.ecologyandsociety.org/issues/responses. php/11763

\section{Acknowledgments:}

We acknowledge the assistance of Sanita Dhaubanjar and Floriane Clement. This study was made possible by the generous support of the American people through the United States Agency for International Development (USAID) under the Digo Jal Bikas (DJB) project. The DJB project seeks to promote sustainable water resource development in Western Nepal through balanced economic growth, social justice, and healthy, resilient ecosystems. The contents of this paper are the responsibility of the authors and do not necessarily reflect the views of USAID or the United States Government.

\section{Data Availability Statement:}

The datalcode that support the findings of this study are available on request from the corresponding author, A.S. The datalcode are not publicly available because of the nature of this study. The interviews that were conducted include respondent names, locations, and household details, as well as other sensitive details related to casteism in Nepal. We do not wish to compromise the privacy of research participants.

\section{LITERATURE CITED}

Adhikari, D. 2006. Hydropower development in Nepal. NRB Economic Review 18:70-94. [online] URL: https://EconPapers. repec.org/RePEc:nrb:journl:v:18:y:2006:p:70-94

Agoramoorthy, G. 2015. Sacred rivers: their spiritual significance in Hindu religion. Journal of Religion and Health 54(3):1080-1090. https://doi.org/10.1007/s10943-014-9934-Z

Alston, M., and R. Mason. 2008. Who turns the taps off? Introducing social flow to the Australian water debate. Rural Society 18(2):131-139. https://doi.org/10.5172/rsj.351.18.2.131

Anderson, D., H. Moggridge, P. Warren, and J. Shucksmith. 2015. The impacts of 'run of river' hydropower on the physical and ecological condition of rivers. Water and Environment Journal 29 (2):268-276. https://doi.org/10.1111/wej.12101

Arthington, A. H., A. Bhaduri, S. E. Bunn, S. E. Jackson, R. E. Tharme, D. Tickner, B. Young, M. Acreman, N. Baker, S. Capon, A. C. Horne, E. Kendy, M. E. McClain, N. L. Poff, B. D. Richter, and S. Ward. 2018. The Brisbane Declaration and global action agenda on environmental flows (2018). Frontiers in Environmental Science 6:45. https://doi.org/10.3389/fenvs.2018.00045

Aryal, R. S., and G. Rajkarnikar, editors. 2011. Water resources of Nepal in the context of climate change. Water and Energy Commission Secretariat, Kathmandu, Nepal. [online] URL: https://www.wecs.gov.np/uploaded/water-recource-climate-change. pdf

Bennett, N. J. 2016. Using perceptions as evidence to improve conservation and environmental management. Conservation Biology 30(3):582-592. https://doi.org/10.1111/cobi.12681

Bharati, L., P. Gurung, P. Jayakody, V. Smakhtin, and U. Bhattarai. 2014. The projected impact of climate change on water availability and development in the Koshi basin, Nepal. Mountain Research and Development 34(2):118-130. https://doi.org/10.1659/ MRD-JOURNAL-D-13-00096.1

Biggs, B. J. F., V. I. Nikora, and T. H. Snelder. 2005. Linking scales of flow variability to lotic ecosystem structure and function. River Research and Applications 21(2-3):283-298. https://doi.org/10.1002/ $\underline{\operatorname{rra} .847}$

Crosgrove, W. J., and F. R. Rijsberman. 2000. World water vision: making water everybody's business. Earthscan, London, UK.

Crow, S. K., G. T. Tipa, D. J. Booker, and K. D. Nelson. 2018. Relationships between Maori values and streamflow: tools for incorporating cultural values into freshwater management decisions. New Zealand Journal of Marine and Freshwater Research 52(4):1175-8805. https://doi.org/10.1080/00288330.2018.1499538

Devkota, L. P., and D. R. Gyawali. 2015. Impacts of climate change on hydrological regime and water resources management of the Koshi River basin, Nepal. Journal of Hydrology: Regional Studies 4(B):502-515. https://doi.org/10.1016/j.ejrh.2015.06.023

Eriyagama, N., L. Bharati, R. T. Shah, and A. Sharma. 2019. Western Nepal environmental flow calculator (WENEFC). Unpublished technical report, Digo Jal Bikas project, Western Nepal. International Water Management Institute, Lalitpur, Nepal. 
Food and Agriculture Organization (FAO). 2018. Nepal at a glance. FAO, Rome, Italy. [online] URL: http://www.fao.org/ nepal/fao-in-nepal/nepal-at-a-glance/en/

Forslund, A., B. M. Renöfält, S. Barchiesi, K. Cross, S. Davidson, T. Farrell, L. Korsgaard, K. Krchnak, M. McClain, K. Meijer, and M. Smith. 2009. Securing water for ecosystems and human well-being: the importance of environmental flows. Swedish Water House report 24. Stockholm International Water Institute, Stockholm, Sweden. [online] URL: http://www.siwi.org/ publications/securing-water-for-ecosystems-and-human-well-beingthe-importance-of-environmental-flows/

Harmsworth, G. R., R. G. Young, D. Walker, J. E. Clapcott, and T. James. 2011. Linkages between cultural and scientific indicators of river and stream health. New Zealand Journal of Marine and Freshwater Research 45(3):423-436. https://doi.org/10.1080/002$\underline{88330.2011 .570767}$

Hartmann, A., O. Moog, and I. Stubauer. 2010. "HKH screening": a field bio-assessment to evaluate the ecological status of streams in the Hindu Kush-Himalayan region. Hydrobiologia 651:25-37. https://doi.org/10.1007/s10750-010-0288-6

International Hydropower Association (IHA). 2018. 2018 hydropower status report. International Hydropower Association, London, UK. [online] URL: https://www.hydropower.org/ publications/2018-hydropower-status-report

International Water Management Institute (IWMI). 2018. Socioeconomic situation of Digo Jal Bikas project's river basin areas. Unpublished research report. IWMI, Lalitpur, Nepal.

Jain, S. K., and P. Kumar. 2014. Environmental flows in India: towards sustainable water management. Hydrological Sciences Journal 59(3-4):751-769. https://doi.org/10.1080/02626667.2014.896996

King, J. M. 2016. Environmental flows: building block methodology. Pages 1-4 in C. M. Finlayson, M. Everard, K. Irvine, R. J. McInnes, B. A. Middleton, A. A. van Dam, and N. C. Davidson, editors. The wetland book. Springer, Dordrecht, The Netherlands. https://doi.org/10.1007/978-94-007-6172-8 346-1

Kumar, D. 2017. River Ganges - historical, cultural and socioeconomic attributes. Aquatic Ecosystem Health and Management 20(1-2):8-20. https://doi.org/10.1080/14634988.2017.1304129

Liu, Y., G. Wu, R. Guo, and R. Wan. 2016. Changing landscapes by damming: the Three Gorges Dam causes downstream lake shrinkage and severe droughts. Landscape Ecology 31(8) 1883-1890. https://doi.org/10.1007/s10980-016-0391-9

Lokgariwar, C., R. Chopra, V. Smakhtin, L. Bharati, and J. O'Keeffe. 2014. Including cultural water requirements in environmental flow assessment: an example from the upper Ganga River, India. Water International 39(1):81-96. https://doi. org/10.1080/02508060.2013.863684

Meinzen-Dick, R., and M. Zwarteveen. 1998. Gendered participation in water management: issues and illustrations from water users' associations in South Asia. Agriculture and Human Values 15:337-345. https://doi.org/10.1023/A:1007533018254

Narayanan, V. 2001. Water, wood, and wisdom: ecological perspectives from the Hindu traditions. Daedalus 130(4):179-206. [online] URL: https://www.amacad.org/publication/water-woodand-wisdom-ecological-perspectives-hindu-traditions

Nzeadibe, T. C., C. K. Ajaero, E. E. Okonkwo, P. U. Okpoko, T. I. Akukwe, and R. F. Njoku-Tony. 2015. Integrating community perceptions and cultural diversity in social impact assessment in Nigeria. Environmental Impact Assessment Review 55:74-83. https://doi.org/10.1016/j.eiar.2015.07.005

Richter, B. D., R. Mathews, D. L. Harrison, and R. Wigington. 2003. Ecologically sustainable water management: managing river flows for ecological integrity. Ecological Applications 13 (1):206-224. https://doi.org/10.1890/1051-0761(2003)013[0206: ESWMMR]2.0.CO;2

Sadoff, C. W., and D. Grey. 2002. Beyond the river: the benefits of cooperation on international rivers. Water Policy 4(5):389-403. https://doi.org/10.1016/S1366-7017(02)00035-1

Shah, R. D. T., and D. N. Shah. 2012. Performance of different biotic indices assessing the ecological status of rivers in the Central Himalaya. Ecological Indicators 23:447-452. https://doi. org/10.1016/j.ecolind.2012.04.001

Shah, R. D. T., S. Sharma, and L. Bharati. 2020. Water diversion induced changes in aquatic biodiversity in monsoon-dominated rivers of Western Himalayas in Nepal: implications for environmental flows. Ecological Indicators 108:105735. https:// doi.org/10.1016/j.ecolind.2019.105735

Shrestha, G., and F. Clement. 2018. Gender differences in water security and capabilities in Far-West Nepal. Pages 83-99 in U. Bhattarai and V. P. Pandey, editors. Proceedings of the 8th Asian regional conference on irrigation in support of evergreen revolution. Nepal National Committee of International Commission on Irrigation and Drainage, Lalitpur, Nepal. [online] URL: https:// www.icid.org/8arc postproceedings.pdf

Singh, R. P. B. 1994. Water symbolism and sacred landscape in Hinduism: a study of Benares (Varasani). Erdkunde 48 (3):210-227. https://doi.org/10.3112/erdkunde.1994.03.05

Tipa, G. 2009. Exploring Indigenous understandings of river dynamics and river flows: a case from New Zealand. Environmental Communication 3(1):95-120. https://doi. org/10.1080/17524030802707818

Wahaj, R., and M. Hartl. 2012. Gender and water: securing water for improved rural livelihoods: the multiple-uses system approach. International Fund for Agricultural Development, Rome, Italy. [online] URL: https://www.ifad.org/documents/38714170/39135645/ Gender+and+Water+-+Security+water+for+rural+livelihoods the+ multiple-uses + system+approach/0b3d7bac-c073-4e8f-8424-2d0$473 \mathrm{~b} 7 \mathrm{~d} 226$

Warrier, S. 2014. Kamandalu: the seven sacred rivers of Hinduism. Mayur University, London, UK. 